\title{
Fenomena Munculnya Tokoh Islam Progresif Muhammadiyah 1980-2019
}

\author{
Asep Sulaeman, Samsudin \\ Universitas Islam Negeri Sunan Gunung Djati Bandung \\ email. Asepsulaiman085@uinsgd.ac.id.
}

\begin{abstract}
Since its first establishment until the productive contemporary period, Muhammadiyah have successfully generated noticeable figures who always oriented towards finding a path to the progress of Muslims. Some of Muhammadiyah progressive figures who are well known such as; M. Syafi'i Maarif and other associates. However, in the journey of contribution from their thoughts, they get criticized and cause controversy. It is believed that their thoughts are considered controversial and contrary to the tradition of thinking of the general public and lead to polemics among Indonesian Muslims. Even, these Muhammdiyah figures and their characters are often labelled as liberal figures who have ever been forbidden by MUI. Concerning this issue, the writers are interested in examining the issue by exploring main purposes: First, an overview progressive Islamic figures of Muhammadiyah. Second, what are the typology of progressive Islamic figures from Muhammadiyah? In this study the writers employed the historical method including heuristics, criticism or analysis, interpretation, and historiography. Based on the research results, the authors determined that the emergence of progressive Islam in contemporary period of Muhammadiyah produced many noticeable figures such as: Ahmad Syafii Maarif, Azyumardi Azra, Bahtiar Effendi, Dawam Raharjo, and Zuly Qadir. Second typology, in this term, progressive Islamic figures from Muhammadiyah are categorized into two typologies namely; Progressive-moderate and progressiveradical.
\end{abstract}

Keywords: Muhammadiyah, Islam Progressive, Figures

\section{Pendahuluan}

Kata progresif berasal dari kata progress dan progression dalam bahasa Inggris yang artinya gerak maju atau seluruh pembicaraan dan upaya untuk maju. Makna Islam progresif yang dimaksud adalah memberikan tekanan penting terhadap pengembangan ilmu pengetahuan 
dan wacana mengenai; keterbukaan, keadilan, toleransi, dan kebutuhan akan pembangunan integritas moral kaum Muslim dalam pembangunan bangsa Indonesia serta pemahaman mengenai keislaman bukan hanya sebagai agama saja, melainkan mengenai upaya menuju kemajuan peradaban. ${ }^{1}$

Kemudian kata Islam progresif itu sering disamakan dengan Islam liberal tetapi tokohnya secara tegas menolak diposisikan sebagai tokoh Islam liberal karena munurut Amin Abdullah kalimat liberal itu hanya cocok digunakan dalam istilah politik dan tidak tepat untuk menjelaskan wilayah akademik, maka kata yang lebih tepat adalah Islam progresif. ${ }^{2}$

Menurut Dawam Raharjo tidak perlu memperdebatkan Islam liberal atau progresif soalnya keduanya memiliki tujuan yang sama yaitu mengupayakan supaya umat Islam maju, solusi adalah harus mengikuti paradigma trilogi Liberalisme, Pluralisme, dan Sekulerisme yang telah terbukti membawa maju dunia Barat. $^{3}$ Ketika seorang individu mendukung trilogi atau salah satunya biasa dikatakan Islam progresif, seperti tokoh; Ahmad Syafii Maarif, Azyumardi Azra, Bahtiar Effendi, Dawam Raharjo, dan Zuly Qadir yang mendukung pemikiran tersebut.

Tokoh-tokoh yang disebutkan di atas secara genealogi berasal dari ormas yang sama, yaitu Muhammadiyah. Dalam perjalannya tokoh-tokoh Islam progresif itu sering menimbulkan kitikan dan kontroversi di internal dan eksternal Muhammadiyah karena pemikirannya dianggap bertentangan dengan tradisi berpikir masyarakat umum, bahkan lebih tajam lagi mereka sering disebut tokoh liberal yang oleh MUI pernah diharamkan. Berdasarkan persoalan ini penulis tertarik untuk menelitinya dengan tujuan: Pertama, diperoleh gambaran siapa tokoh-tokoh Islam progrsif dari Muhammadiyah? Kedua, bagaimana tipologi tokoh-tokoh Islam progrsif dari Muhammadiyah?

${ }^{1}$ Budhy Munawar Rachman, Membela Kebebasan Beragama (Jakarta: The Asia Foundation, 2016)...John M Echol and Hassan Shadly, Kamus Inggris Indonesia (Jakarta: Gramedia, 1987).

${ }^{2}$ Ibid... h. 1045 dan Amin Abdullah, Wawancara pada tanggal 5 November 2018.

${ }^{3}$ Fauzy, Syafik Hasyim, and J.H. Lamardy, Demi Toleransi Demi Pluarlisme (EsaiEsai Untuk Merayakan 65 Tahun M.Dawam Raharjo (Jakarta: Democracy Project, 2012). 
Selanjutnya perlu diketahui bahwa jarang ada karya yang menuliskan secara khusus tokoh Islam progresif Muhammadiyah, kalaupun ada menjelaska Islam progresif sama atau bagian dari Islam liberal, seperti karya Budi Munawar Rahman dan Zuly Qodir, tetapi karya mereka memiliki kontribusi bagi penelitian yang dilakukan penulis. Dengan demikian penelitian ini penting dilakukan karena belum banyak yang meneliti pemikiran Islam progresif Muhammadiyah dan diharapkan memberi sumbangan terhadap perkembangan sejarah pemikiran Islam.

Metode dalam penelitian ini adalah metode sejarah. Metode tersebut terdiri dari empat tahap, yakni; heuristik, kritik, interpretasi, dan historiografi. Heuristik bukan merupakan tahapan penemuan sumber saja tetapi pencarian sumber atau to find atas usaha pencarian sumber dan penghimpunan semua jejak masa lampau. ${ }^{4}$ Melalui tahapan heuristik, penulis mendapatkan sumber berupa Majalah dan buku karya tokoh Islam progresif. Kemudian melakukan wawancara dengan Amin Abdullah dan Zuly Qadir.

Setelah tahapan heuristik dilanjutkan ke tahap kritik, yang menurut Helius Sjamsuddin, kritik sumber merupakan upaya pencarian kebenaran (truth), sejarawan perlu mengemukakan mana sumber yang benar dan yang palsu, mana sumber yang mungkin dan yang mustahil, ${ }^{5}$ kemudian mengelompokannya pada dua bagian, yaitu primer dan sekunder. Interpretasi adalah proses menafsirkan sumber yang sudah melalui tahap kritik. Dari beberapa jenis interpretasi, penulis mencoba nenggunakan interpretasi psikologis, yang melihat asal-usul dan lingkungan ormas Muhammadiyah. Tahapan berikutnya adalah historiografi adalah proses merangkai cerita sejarah dengan memusatkan pada keahlian mengarang (art of writing). Dalam tahapan ini penulis melakukan: Pertama penyeleksian tokoh-tokoh dengan didukung fakta-fakta. Kedua melakukan imajinasi tulisan sejarah untuk memperoleh mata rantai yang menghubungkan tokoh-tokoh yang terpisah. ${ }^{6}$

\footnotetext{
${ }^{4}$ Nina Herlina Lubis, Metode Sejarah (Jawa Barat: Yayasan MSI, 2015).

${ }^{5}$ Helius Sjamsuddin, Metodologi Sejarah (Yogyakarta: Ombak, 2012).

${ }^{6}$ Lubis, Metode Sejarah (Jawa Barat: Yayasan MSI, 2015) h.45-60.
} 


\section{Hasil dan Pembahasan}

\section{Lahir dan Berkembangnya Muhammadiyah}

Ahmad Dahlan adalah orang Yogyakarta yang pernah belajar secara formal di Mekkah kepada Imam Mesjid Al-Haram yang bernama Syakh Ahmad Khatib. Kemudian secara informal mempelajari pemikiran Muhammad Abduh, melalui majalah Al'Urwatul Wutsqa dan tafsir AlManar. Antara Syakh Ahmad Khatib gurunya dan Muhammad Abduh yang dikenalnya melalui tulisannya, tampaknya pemikiran modernis Muhammad Abduh lebih banyak memengaruhinya, yang inti pemikirannya adalah ingin mengembalikan Islam ke ajaran utama, yaitu kembali ke Alquran dan Sunnah, dibukanya pintu ijtihad, dan menyesuaikan pelaksanaan ajaran Islam dengan kehidupan modern. ${ }^{7}$

Walaupun pada awalnya gagasan progresif ditolak tetap mulai berubah ketika pulang ke Yogyakarta setelah melaksanakan ibadah haji yang kedua tahun 1903. Ia mulai lagi menyebarkan pemikiran ke masyarakatnya. Pada tanggal 18 November 1912 bertepatan dengan tanggal 18 Dzulhijjah $1330 \mathrm{H}$, Ahmad Dahlan mendeklarasikan berdirinya Persyarikatan Muhammadiyah di Kauman Yogyakarta dengan tujuan menyebarkan pengajaran Kangjeng Nabi Muhmmad saw kepada penduduk Bumiputra dan memajukan agama Islam. ${ }^{8}$

Setelah melakukan deklarasi dan mendapat ijin dari pihak pemerintahan Kolonial Belanda, cabang Muhammadiyah di berbagai daerah mulai didirikan. Dengan mengadopsi strategi kelompok misionaris

7 Diambil dari tulisan Bambang Haryamurti Wartawan Panji Masyarakat. Yang menejlaskan Ahmad Dahlan setelah melakukan haji yang kedua, sempat berguru selama dua tahun kepada Syakh Ahmad Khatib, ulama kelahiran Bukitinggi 1855 yang berkedudukan sebgai imam masjid Al-Haram, yang juga gurunya Hasyim Asy'Ari (pendiri NU). Tetapi ketika di Mekkah lebih terpengaruh oleh pemikiran Muahmmad Abduh dari Mesir, melalui majalah Al'Urwatul Wutsqa dan tafsir Al-Manar yang ditulis oleh Muhammad Abduh dan gurunya Jalaludin Al-Afghani dan muridnya Muhammad Rasyid Ridha. Diterbitkan di Paris Prancis (1987:65; Nasution, 1975: 62). ${ }^{8}$ Hisyam and Taupik Abdullah, Indonesia Dalam Arus Sejarah (Jakarta: Ichtiar van Hoeve, 2012)...Asep Ahmad Hidayat, Studi Islam Di Asia Tenggara (Bandung: Pustaka Setia, n.d.)...Deliar Noer, Gerakan Moderen Islam Di Indonesia 1900-1942 (Jakarta: LP3ES, 1995). 
Kristen Yogyakarta, ia membuka lembaga pendidikan, panti asuhan, dan Pertolongan Kesedjahteraan Oemat (PKO). Usaha-usahanya ini mendapat sambutan dari berbagai kalangan sehingga pada tahun 1925 sampai 1930 ia memiliki anggota 4000 orang. ${ }^{9}$ Menurut Rickleffs Muhammadiyah mulai mengalami perkembangan yang signifikan dari berbagai bidang sehingga menurutnya bahwa pada tahun 1925-an kemajuan sejarah Islam modern Indonesia adalah kemajuan Muhammadiyah. ${ }^{10}$ Kemudian Muhammadiyah berhasil melahirkan tokoh-tokoh yang memiliki kontribusi besar bagi kemajaun bangsa dan umat Islam Indonesia. Mulai awal berdiri sampai priode kontemporer produktif melahirkan tokoh-tokoh yang progresif. Pada priode awal tokoh Ahmad Dahlan sebagai pendiri Muhammadiyah, bisa dikatakan tokoh yang progresif karena mencari berbagai cara mencari jalan kemajuan umatm walaupun menimbulkan kontroversi di masyarakat, kemudian pada priode kontemporer melahirkan tokoh progresif seperti; M. Syafi'i Maarif, Dawam Rahardjo, Azyumardi Azra, Bahtiar Effendi, Dawam Raharjo, dan Zuly Qadir.

\section{Munculnya Tokoh Progresif Muhammadiyah}

\section{Ahmad Syafii Maarif}

Ahmad Syafii Maarif lahir di Sumpur Kudus Sumatera Barat pada tanggal 31 Mei 1935. Ia mendapat Gelar sarjana sejarah di IKIP Yogyakarta. Kemudian memperoleh gelar MA dan $\mathrm{PhD}$ dari Ohio University dan the University of Chicago AS. Ia pernah menjadi Ketua Umum PP Muhammadiyah periode 2000- 2004. ${ }^{11}$

Setelah Syafii Maarif mengikuti kuliah dengan gurunya Fazlur Rahman termasuk Islam progresif karena pendapatnya yang menolak negara Islam. Menurutnya poin penting dalam Islam adalah moral yang

\footnotetext{
${ }^{9}$ Hisyam and Taupik Abdullah, Indonesia Dalam Arus Sejarah (Jakarta: Ichtiar van Hoeve, 2012) h 338-339.

${ }^{10}$ Hisyam and Taupik Abdullah, Indonesia Dalam Arus Sejarah (Jakarta: Ichtiar van Hoeve, 2012) h 339.

${ }^{11}$ Fauzy, Hasyim, and Lamardy, Demi Toleransi Demi Pluarlisme (Esai-Esai Untuk Merayakan 65 Tahun M.Dawam Raharjo...Rachman, Membela Kebebasan Beragama.Ahmad Syafii Maarif, Memoar Seorang Anak Kampung (Yogyakarta: Ombak, 2013).
} 
perlu menjadi landasan norma bagi masyarakat. Jika Indonesia menginginkan negeri ini adil dan makmur, maka syariat Islam perlu digabungkan dengan sistem hukum nasional melalui proses demokratisasi. Ia mengutip istilah Bung Hatta yang berbunyi "Janganlah gunakan filsafat gincu, tampak tetapi tak terasa; pakailah filsafat garam, tak tampak tapi terasa,". Artinya negara Indonesia merupakan sebuah negara yang berlandaskan Pancasila (bukan Islam), akan tetapi nilai-nilai moral Islam harus selalu diketengahkan dalam kehidupan bernegara dan bermasyarakat; meskipun "Negara Islam" tidak tampak, tapi moral Islam tetap dijalankan. ${ }^{12}$

Kemudian pembahasan berikutnya tentang pluralisme, di mana menurut konsep pluralisme adalah sebuah pengakuan gagasan mengenai realitas kemajemukan. Ia mengajak setiap pribadi untuk menyadari dan mengenaal keberagaman di segala bidang kehidupan, seperti sosial, budaya, agama, sistem politik, tradisi lokal, etnisitas, dan sebagainya. Oleh sebab itu, dalam Alquran surat Al-Hujarat menegaskan bahwa: Kami menciptakan kalian syu'uban wa qaba'ila (berbangsa- bangsa dan bersuku-suku) li-ta'arafu (supaya saling berkenalan). Dengan demikian, bukan hanya untuk saling mengenal, melainkan secara implisit di sana ada juga ajakan untuk bertukar nilai-nilai peradaban, untuk saling memberi dan menerima keberbagaian atau pluralitas. ${ }^{13}$

\section{Bahtiar Effendy}

Bahtiar Effendy lahir di Ambarawa pada tanggal 10 Desember 1958. Menyelesaikan Studi Asia Tenggara dari Ohio University Athens dan mendapatkan gelar MA pada tahun 1988 dan Ilmu Politik dari Ohio State University Colombus, tahun 1991. Gelar Doktor Ilmu Politik diperolehnya dari Ohio State University tahun $1994 .{ }^{14}$

Menurutnya bangsa Indonesia tidak bisa merendahkan apa yang dilakukan oleh Sukarno, Hatta, Natsir, serta founding fathers lainnya.

\footnotetext{
${ }^{12}$ Ahmad Syafii Maarif, Dinamika Islam (Yogyakarta: Shalahuddin Press, 1996)h 26.

${ }^{13}$ Budhy Munawar Rachman, Membela Kebebasan Beragama (Jakarta: The Asia Foundation, 2016) h. 177.

${ }^{14}$ Ibid.h. 210 .
} 
Mereka telah memikirikan mengenai bangsa Indonesia dengan sangat serius sehingga menemukan bahwa di Indonesia tidak mungkin menerapkan negara agama ataupun negara sekuler karena khalifah hanya dapat diberlakukan pada waktunya. Umat Islam Indonesia harus menyadari tidak mungkin lagi mengusung Pan-Islamisme karena nasionalisme dan negara pada bangsa ini sudah menjadi fakta yang tidak bisa dihindari. Baginya maju mundurnya demokrasi tidak dipengaruhi oleh agama, melainkan lebih dipengaruhi oleh masalah-masalah sosialpolitik. Jika bangsa ini konsisten dengan demokrasi, mestinya orang dibebaskan mau memakai azas apa pun, termasuk Islam. ${ }^{15}$

Hanya Tuhan yang tahu akan kebenaran keagamaan, sebaiknya perlu meningkatkan sikap sabar, bahwa mungkin berada pada pihak yang salah. Untuk itu, mengadakan dialog menjadi penting daripada saling mengklaim kebenaran. Inilah prinsip kemanusiaan, prinsip hablun min alnas, yang harus terus disosialisasikan. ${ }^{16}$

\section{M. Dawam Raharjo}

M. Dawam Rahardjo lahir di Solo pada tanggal 20 April 1942. Meninggal dunia di Jakarta pada hari Kamis tanggal 30 Mei 2018. Pernah masuk ke Fakultas Ekonomi UGM. Pernah menjadi pengurus pusat Muahmmadiyah. ${ }^{17}$

Menurutnya gerakan pembaruan telah mendua: Pertama, menuju ke arah modernitas dan progresif; Kedua, ke arah sebaliknya, yaitu puritanisme dan salafiyah. Kedua gerakan tersebut muncul dalam gerakan Muhammadiyah di Indonesia sehingga menghasilkan dua kubu, yaitu kubu fundamentalis dan kubu progresif. Bahkan, akhir-akhir ini, kubu progresif telah berhasil disingkirikan oleh kubu fundamentalis. Hal ini terjadi dalam kepengurusan Muhammadiyah dalam kepemimpinan Din Syamsuddin. ${ }^{18}$

\footnotetext{
${ }^{15}$ Ibid. h.213, 221 dan 225.

${ }^{16}$ Op. Cit. h. 231.

${ }^{17}$ Fauzy, Hasyim, and Lamardy, Demi Toleransi Demi Pluarlisme (Esai-Esai Untuk Merayakan 65 Tahun M.Dawam Raharjo.

${ }^{18}$ Fauzy, Hasyim, and Lamardy, Demi Toleransi Demi Pluarlisme (Esai-Esai Untuk Merayakan 65 Tahun M.Dawam Raharjo) h. 473..
} 
Kemudian menurutnya, salah satu kunci untuk kemajuan adalah sekulerisme dan sekulerisasi. Perlu dibedakan antara sekulerisasi yang lebih menekankan pada proses dengan sekulerisme yang menuju pada pemahaman dan ideologi. Keduanya dapat dibedakan dari pemahaman bahwa sekulerisme adalah suatu paham yang mengandung tujuan-tujuan tertentu dan prosesnya dicapai, sementara sekulerisasi adalah suatu proses pengembangan masyarakat. ${ }^{19}$

Hampir semua negara Muslim modern dewasa ini menggunakan sekulerisme. Konteks sekarang, hanya ada dua negara saja yang dapat disebut sebagai Negara Islam. Pertama, adalah Saudi Arabia yang tidak memiliki konstitusi sendiri dan menjadikan Alquran dan Al-Sunnah sebagai konstitusi langsung yang mewakili Sunni. Kedua, Iran yang mewakili aliran Syi'ah. ${ }^{20}$

Kebebasan yang sama, keadilandan kesetaraan merupakan hasil yang diperoleh setiap orang dengan adanya paham pluralisme. Namun juga dianjurkan untuk melakukan dialog untuk saling memahami serta toleransi. Dalam hal itu, Indonesia memiliki istilah yang menarik, yaitu: Bhinneka Tunggal Ika: Berbeda tapi bersatu; bersatu dalam perbedaan. ${ }^{21}$

\section{Zuly Qadir}

Zuly Qadir yang lahir di Banjarnegara pada tanggal 22 Juli 1971, menyelesaikan sarjana di Universitas Muhammadiyah dan Universitas Gadjah Mada. Ia mengepalai Litbang majalah Suara Muhammadiyah. ${ }^{22}$

Menurutnya Indonesia adalah negara yang sangat memberikan ruang untuk berpikir merdeka. Berpikir seperti itulah disebut dengan liberal-progresif, sebuah pemikiran yang tidak bisa dilarang dan dihentikan oleh siapa pun di Indonesia. Sekalipun ada yang menghentikannya, seperti yang dilakukan Majelis Ulama Indonesia (MUI) yang mengharamkan sekularsime, pluralisme, dan Progresifisme, itu tidak

\footnotetext{
${ }^{19}$ Budhy Munawar Rachman, Membela Kebebasan Beragama (Jakarta: The Asia Foundation, 2016) h 6 .

${ }^{20}$ Ibid...h.11.

${ }^{21}$ Ibid. h. 17.

${ }^{22}$ Ibid. ...h. dan Elza Peldi Taher, Merayakan Kebebasan Beragama (Bunga Rampai 70 Tahun Djohan Effendi) (Jakarta: Democracy Project, 2011).
} 
bisa dilakukan secara efektif karena berpikir itu akan selalu terjadi selama masih hidup. Oleh sebab itu, seringkali ada kesan bahwa jika seseorang itu dilarang berpikir maka pemikiran itu mati. Padahal sebenarnya yang terjadi tidak demikian, hanya secara formalitas pemikiran itu dilarang tetapi sejatinya terus berlangsung dan Indonesia itulah tempatnya orang berpikir merdeka atau bebas. Selama buah pikirnya tidak melawan negara secara terorganisir dan memobilisasi massa untuk melawan, maka negara membolehkan pemikiran itu berkembang. Namun, jika berefek negatif, pemikiran tersebut dapat dihentikan oleh aturan hukum yang berlaku dalam sebuah negara ${ }^{23}$.

Selanjutnya sekularisme adalah proses yang tidak mungkin ditolak. Prosos memisahkan antara wilayah duniawi dan ukhrawi merupakan proses yang tidak dapat dinafikan. Orang Muslim sering mengatakan bahwa semua perbuatan manusia adalah ibadah, tapi harus segera ditegaskan bahwa ada hal lain, seperti soal pemerintahan, ekonomi, sosial, dan politik yang menurutnya, tidak ada kaitannya dengan ibadah. ${ }^{24}$

Kebebasan beragama seharusnya dibela oleh pemerintah karena Indonesia merupakan negara hukum dan konstitusi memberikan amanat tentang ini. Siapa pun di Indonesia berhak menganut agama apa pun selain agama resmi negara. Bahkan secara individual, seseorang mungkin saja tidak menganut agama apa pun, namun secara publik atau jika mengajak orang untuk tidak beragama itu bertentangan dengan prinsip Pancasila yang mengharuskan warga negara Indonesia beriman atau memiliki keyakinan pada Tuhan Yang Maha Esa. ${ }^{25}$

\section{Tipologi tokoh-tokoh Islam Progresif}

Pengertian progresif-moderat, secara bahasa berasal dari kata progress dan progression yang artinya gerak maju dan moderate berarti lembut, tengah atau orang moderat, ${ }^{26}$ jadi progresif-moderat adalah tokoh atau

${ }^{23}$ Zuly Qadir, Wawancara tanggal 19 April 2018

${ }^{24}$ Rachman, Membela Kebebasan Beragama h. 1757.

${ }^{25}$ Zuly Qadir, Wawancara tanggal 19 April 2018.

${ }^{26}$ Echol and Shadly, Kamus Inggris Indonesia h. 384-450. 
golongan yang menganut paham progresif tetapi moderat atau halus dalam mendukung gagasannya.

Tokoh yang termasuk tipologi ini adalah: Ahmad Syafii Maarif, Azyumardi Azra, M. Syafii Anwar, dan Bahtiar Effendi. Seperti pendapatpendapatnya di atas, mereka mendukung gagasan trilogi liberalisme, sekulerisme, dan pluralisme Islam progresif tetapi tetap melakukan keritik terhadap gagasan tersebut dan mendukung gagasan Islam yang lebih substansial.

Selanjutnya tipologi progresif-radikal, secara bahasa berasal dari kata radical berarti sampai ke aka-akarnya, atau seseorang yang radikal (Echols dan Shadilly, 1987: 463). Jadi progresif-radikal adalah tokoh atau golongan yang menganut paham radikal dan sampai mendalam serta menggunakan metode yang lebih radikal, seperti:

Dawam Raharjo dan Zuly Qadir. Kerangka pikirnya bisa dilihat dari pendapat-pendapatnya di atas yang mendukung sepenuhnya gagasan liberalisme, sekulerisme, dan pluralisme baik secara substansi maupun secara formal serta harus berani secara tegas mendukung wacana pemikiarn progresif.

\section{Simpulan}

Berdasarkan pada pembahasan yang telah dilakukan penulis, maka dapat ditarik beberapa simpulan, di antaranya; perlu dicatat bahwa Muhmmadiyah sebagai ormas di priode kontemporer melahirkan tokohtokoh Islam progresif, seperti tokoh; Ahmad Syafii Maarif, Ahmad Fuad Fanani, Azyumardi Azra, Bahtiar Effendi, Dawam Raharjo, M. Syafii Anwar, dan Zuly Qadir.

Kemudian tipologi pemikiran tokoh Islam progresif dikatagorikan ke dua tipologi, yaitu tipologi; progresif-moderat dan progresif-radikal. Yang termasuk tipologi Islam progresif-moderat di antaranya: Ahmad Syafii Maarif, Azyumardi Azra, M. Syafii Anwar, dan Bahtiar Effendi. Yang termasuk tipologi progresif-radikal di antaranya: Dawam Raharjo, Ahmad Fuad Fanani, dan Zuly Qadir 
Fenomena Munculnya Tokoh Islam Progresif Muhammadiyah 1980-2019 | Asep Sulaeman, Samsudin

\section{Daftar Sumber}

\section{A. Sumber Buku}

Bagir, Haedar. 1993. Satu Islam. Bandung: Mizan

Echols, John M dan Hassan Shadly. 1987. Kamus Inggris Indonesia. (Jakarta: Gramedia)

Fauzi, Syafiq Hasyim, dan J.H. Lamardy. 2012. Demi Toleransi Demi Pluarlisme (Esai-Esai Untuk Merayakan 65 Tahun M. Dawam Raharjo). Jakarta: Democracy Project.

Hidayat, Asep Ahmad dkk. Studi Islam di Asia Tenggara. Bandung: Pustaka Setia.

Herlina Lubis, Nina 2015. Metode Sejara. Bandung: Yayasan MSI Jawa Barat

Hisyam dan Taupik Abdullah 2012. Indonesia dalam Arus Sejarah . Jakarta: Ichtiar van Hoeve.

Maarif, Ahmad Syafii. 2013. Memoar Seorang Anak Kampung. Yogyakarta: Ombak.

------- 1996. Dinamika Islam. Yogyakarta: Shalahuddin Press.

Nasution, Harun. 1975. Pembaruan dalam Islam (Sejarah pemikiran dan Gerakan). Jakarta: Bulan Bintang.

Noer, Deliar. 1995. Gerakan Moderen Islam di Indonesia 1900-1942. Jakarta: $\quad$ LP3ES

Rachman, Budhy Munawar. 2016. Membela Kebebasan Beragama (Buku 1-4). Jakarta:The Asia Foundation.

Sjamsuddin, Helius. 2012. Metodologi Sejarah. Yogyakarta: Ombak Taher, Elza Peldi. 2011. Merayakan Kebebasan Beragama (Bunga Rampai 70 Tahun Djohan effendi). Jakarta: Democracy Project

\section{B. Sumber Jurnal, Majalah, dan Koran}

Maarif, Ahmad Syafii 1985. " Islam dan Masa depan Indonesia”, dalam Panji Masyarakat. 1 Oktober Juli.

\section{Sumber Wawancara}


Fenomena Munculnya Tokoh Islam Progresif Muhammadiyah 1980-2019 | Asep Sulaeman, Samsudin

Abdullah, Amin. (66 Tahun).

Beliau adalah tokoh pemikir Islam Liberal dari Muhammadiyah.

Wawancara di Bandung, tanggal 6 November 2018

Qadir, Zuly. (47 Tahun)

Kordinator Jaringan Islam Muda Muhammadiyah (JIMM)

Wawancara dilakukan secara online, tanggal 19 April 2018. 